Agro-Science Journal of Tropical Agriculture, Food, Environment and Extension Volume 13 Number 1 January 2014 pp. 8 - 17

ISSNIII9-7455

\title{
EVALUATION OF PERFORMANCES OF BROILERS RAISED UNDER DIFFERENT FLOOR SPACE GEOMETRIES IN SOUTH WESTERN NIGERIA
}

\author{
Wasiu Agunbiade Lamidi \\ College of Agriculture, Ejigbo Campus, Osun State University, Osogbo, Nigeria \\ e-mail address: iwasiuagunbiade@yahoo.com
}

\begin{abstract}
The study focused on the performances of broilers raised under different floor space areas and flock sizes in deep litter housing. Pens' floor areas $\left(F_{1} S=2400 \mathrm{~cm}^{2}, F_{2} S=2600 \mathrm{~cm}^{2}, F_{3} S=2800 \mathrm{~cm}^{2}\right.$ and $F_{4} S=3000 \mathrm{~cm}^{2}$ ) were used with each housing 4 birds and also 4 levels of flock sizes at constant floor space area variations $\left(S_{1} D=2800 \mathrm{~cm}^{2}, S_{2} D=4200 \mathrm{~cm}^{2}, S_{3} D=5600 \mathrm{~cm}^{2}\right.$ and $\left.S_{4} D=7000 \mathrm{~cm}^{2}\right)$ housing $n=4,6,8$ and 10 birds, respectively. Among the parameters measured were weight gains by birds, litter weights- its dry matter content and $\mathrm{pH}$ values and feed conversion ratio (FCR). Proximate analysis of broiler meat was done for meat quality evaluation. Floor space (FS) had significant effect $(P \leq 0.05)$ on the birds' weights gain and weights' uniformities and growth; FS also had significant effect $(P \leq 0.05)$ on the litter weights, dry matter content and $p H$ values of the litter. Also, statistical differences were observed for all the proximate values in $F_{3} S$ and $S_{1} D$ and in $F_{1} S$ cells. The $2800 \mathrm{~cm}^{2}$ of 4 birds at $700 \mathrm{~cm}^{2} /$ bird floor geometry gave highest weight gain $(199.3 \mathrm{~g}$ $\pm 4.28)$, carcass dressed weight $(1450.0 \mathrm{~g} \pm 5.66)$ and $F C R(7.88 \pm 0.13)$ at both floor space area/floor geometry (FS) and flock size/stocking density (SD) variations. The $2800 \mathrm{~cm}^{2}$ of 4 birds at $700 \mathrm{~cm}^{2} /$ bird floor space was considered best in the research.
\end{abstract}

Key words: carcass dressed weights, dry matter, feed conversion ratio floor geometry flock size

\section{INTRODUCTION}

Poultry farming is important among livestock farming in the world especially of recent because of many benefits that are derived from it (Agric Business, 2010). Table meat as broilers sometimes called are reared under intensive care deep litter housing in which birds are kept on floors laid with litter (Vegetarian Society, 2003). For them to appreciably express their genetic potential fully, they must have adequate floor area, feed and water throughout the rearing period. However, Feddes et al., (1999) stated that high flock sizes (also called stocking densities) could cause stress to broiler chickens in several ways, like difficulty in dissipating heat from their bodies, poor air space quality due to inadequate air exchange, increased in ammonia levels and difficulty for birds in their equal access to feed and water. Flock sizes, floor space areas, feed and water quality and management affect yield of the bird's meat (Goksoy et al., 1999). Also higher mortality rate (due to cannibalism) was observed (Hall, 2001) from higher flock size when flock size is greater than what bird specifically needs. Thus, study in flock size for a particular total floor space litter housing for broilers needs to be researched.

Also, temperature determines to a large extent the efficiency of a poultry house. The normal temperature of adult chickens depends on the breed and liveweight and they stay to their wider range of thermo-comfort level of temperature since they are biologically equipped to cope with fluctuating temperatures diurnally and seasonally (Bruce, 1987). Increase in temperature and moisture content of the litter brings strong increase in the ammonia concentration. No environmental factor can be treated in isolation since all of them have 
interactive effect on birds' productivity. Dry matter and water contents of the litter are both responsible for the promotion of activities of micro-organisms which cause higher temperature inside the litter and to its surface and consequently hasten degradation process of uric acid, volatisation of water vapour and carbondioxide, and organic materials is released as ammonia (Bonazzi et al., 1987; Jacobsen, 1987). The thickness of the litter layer, its density and its surface area that exposes to the air, its looseness and its percentage dry matter content determine its quality, and all these determine its ammonia concentration (Groot Koerkamp, 1995). All these factors are dependent on floor space and flock size as they affect birds' performance and production.

Several scholars have researched into the standard floor space requirements and stocking densities/flock sizes for the broilers (May et al., 1997). British Codes (2000) and Vegetarian Society (2003) recommended $34 \mathrm{~kg} / \mathrm{m}^{2}$ and 500 $\mathrm{cm}^{2}$ FS respectively per bird in the temperate countries; Feddes et al. (1999) recommended FS of $675 \mathrm{~cm}^{2} /$ bird in the tropics and Stewart (1996) reported $624 \mathrm{~cm}^{2}$. These conflicting standards by various authors on floor space requirements for birds especially in the tropical regions of the world necessitate this research.

The aim of the research was to add to the existing knowledge in broiler litter housing in the tropics by providing total floor space for a particular flock size at practical conditions for higher yield. This research evaluates the performances of broilers when raised on various floor space areas and flock sizes as evident in birds' growth performances, weights' gains/loss, feed conversion ratio and on some of their litter's properties when raised in south western part of Nigeria.

\section{MATERIALS AND METHODS}

The study was carried out at the Poultry Section of the Teaching and Research Farm, Obafemi Awolowo University, Ile-Ife. Ile-Ife is in the rain forest zone of Nigeria, situated at longitude $5^{\circ} 33^{\prime} \mathrm{E}$ and latitude $07^{\circ} 28^{\prime} \mathrm{N}$. Four different floor space (FS) areas $\mathrm{F}_{1} \mathrm{~S}=2400 \mathrm{~cm}^{2}$, $\mathrm{F}_{2} \mathrm{~S}=2600 \mathrm{~cm}^{2}, \mathrm{~F}_{3} \mathrm{~S}=2800 \mathrm{~cm}^{2}$ and $\mathrm{F}_{4} \mathrm{~S}=3000$ $\mathrm{cm}^{2}$ were stocked with 4 birds each, thus making floor spaces to be $600 \mathrm{~cm}^{2}, 650 \mathrm{~cm}^{2}, 700 \mathrm{~cm}^{2}$ and $750 \mathrm{~cm}^{2}$ per bird respectively for varying floor spaces at constant flock size (SD). Again, there were four different pens: $S_{1} D=2800 \mathrm{~cm}^{2}$, $\mathrm{S}_{2} \mathrm{D}=4200 \mathrm{~cm}^{2}, \mathrm{~S}_{3} \mathrm{D}=5600 \mathrm{~cm}^{2}$ and $\mathrm{S}_{4} \mathrm{D}=$ $7000 \mathrm{~cm}^{2}$ with $4,6,8$ and 10 birds, respectively, for varying flock sizes at constant floor space per bird. It was $2 \times 4 \times 3$ factorial design, there were three replicates each with cell $\mathrm{F}_{1} \mathrm{~S}=2400$ $\mathrm{cm}^{2}\left(\mathrm{n}=\right.$ number of birds $=4$ ) labeled $\mathrm{F}_{1} \mathrm{~S}_{1}, \mathrm{~F}_{1} \mathrm{~S}_{2}$ and $\mathrm{F}_{1} \mathrm{~S}_{3}$. Similarly, cells $\mathrm{F}_{2} \mathrm{~S}=2600 \mathrm{~cm}^{2}(\mathrm{n}=$ 4), $F_{3} S=2800 \mathrm{~cm}^{2}(\mathrm{n}=4)$ and $F_{4} S=3000 \mathrm{~cm}^{2}$ $(\mathrm{n}=4)$ also replicated three times for varying floor spaces, constant flock sizes (SD).

For varying flock sizes and constant floor space experiment, there were replicated pens labeled $S_{1} D_{1}, S_{1} D_{2}$ and $S_{1} D_{3}$ to make cell $\mathrm{S}_{1} \mathrm{D}=2800 \mathrm{~cm}^{2}(\mathrm{n}=4)$; cells: $\mathrm{S}_{2} \mathrm{D}=4200 \mathrm{~cm}^{2}$ $(\mathrm{n}=6), \mathrm{S}_{3} \mathrm{D}=5600 \mathrm{~cm}^{2}(\mathrm{n}=8)$ and $\mathrm{S}_{4} \mathrm{D}=7000$ $\mathrm{cm}^{2}(\mathrm{n}=10)$ and their replicated pens. This was for easy identification during the research. The breed of birds used was shevers (shevers are breed of broiler, (another breed is named Anak, not used in this research) and were raised from day old to eight weeks. They were reared under the same condition and fed ad libitum, first with grower mash till four weeks and then finisher diet/ration for the rest period (May et al., 1997). Since each bird in the different pens has the whole pen floor area to itself, the flock size thereby varies as the floor spaces as the number of birds varies.

Feeds and water were supplied to the birds equally as regards the flock size/stocking density SD variations with accurate measurement using measuring cylinder model F100 $\mathrm{ml}$. The 4 birds in a pen were given $4 \times 1$ bird's feed and water; 6 birds were given $6 \times 1$ bird's feed and water, the same went for 8 and 10 birds, all were treated equally. The whole arrangement still provided the constant amount of feeding space per bird. Wood shavings were provided for them as litter materials and were removed weekly for appropriate analysis as regards the determination of percent dry matter and percent moisture content on daily basis over a period of a week when the litter was replaced (Stewart, 1996).

The relative humidi inside and outside the house and temperature of the litter, temperature of the air above the litter and the temperature outside the house, were all determined for each of the pen daily and for the week. Measured daily were the weights and volumes of the litter starting from the first day of introduction into the pen to the day of their removal, since each litter introduced spent a week in their respective pens, weekly values of these weights and volume and their densities were compared with each other for the period of the experiment. Triple beam balance (0.01 ccuracy) of capacity $2610+$ $0.01 \mathrm{gm}$ was used for all the weights measured throughout the period of the experiment. The $\mathrm{pH}$ values of the litter were taken on daily basis with the $\mathrm{pH}$ scale.

To calculate the weight gain over a period of time, the weekly liveweight gain per bird were calculated and their averages were evaluated after $8^{\text {th }}$ wee for the bird in a pen. The weight gains per bird were measured using 
differences between two weights, and between the initial and final body weights over the period. FCR (dimensionless), was calculated using the formulae as given by Crawford (1990)

$$
\mathrm{FCR}=\frac{\text { feedconsumed }, \mathrm{kg}}{\text { liveweight gain, } \mathrm{kg}}
$$

Also, the reciprocal of FCR is Feed Efficiency,

$$
\text { stated as } \mathrm{FE}=\frac{1}{F C R}
$$

Carcass yield/weight in grammes, that is, the dressed weights (birds' body excluding the feathers, legs, intestines and head) were determined for all the birds in the research, this was to ascertain the productivity index of their rearing to the farmers.

\section{RESULTS AND DISCUSSIONS}

Significant $(\mathrm{P} \leq 0.05)$ effect of the FS and SD were observed on the weights of birds in all the cells, (Table 1), it also shows that there exist statistical differences between the mean values along the row for the FS and SD variations at $(\mathrm{P} \leq 0.05)$, not only on the weights of birds in all the cells but also on the proximate values. Figures $1 \mathrm{a}$ and $\mathrm{b}$, show the weekly weight gain per bird in grammes for varying floor spaces and varying stocking densities respectively. It was observed that growth was retarded in some weeks (between 4th and 6th weeks) in $2400 \mathrm{~cm}^{2}$ in Fig. 1a and $4200 \mathrm{~cm}^{2}$ pens in Fig. $1 \mathrm{~b}$ between 4 th and 8 th weeks, this was due primarily to the size of the floor and the number of birds per pen. Weight gain in pens in cell $2800 \mathrm{~cm}^{2}$ increased in both Fig. 1a and b from week 1 to 8 . For $3000 \mathrm{~cm}^{2}$, in the last five weeks Fig. 1a, the growth rates which was for the determination of carcass weights, the birds' were slaughtered and their blood was allowed to drained off, so as to ensure that no blood was part of their carcass at weighing. Legs and heads were also removed along with the intestines. Some equal meat pieces were removed at the thigh and chest for each of the slaughtered bird for proximate analysis of the percent crude fibre, percent protein, percent moisture content, percent ether and ash contents for meat quality assessment of the birds to evaluate the effects of the floor spaces and flock sizes on them. One way ANOVA was used in the analysis of the results and Duncan multiple range test was used for the separation of the mean values for statistical differences among weight gains and proximate analysis values. weekly weight gain per 7 days of the week, were nearly constant, this was due to the fact that the space was seemingly more than necessary for higher performance of the birds, because they were able to move about than others in their own pens.

The highest weight gains (50, 60 and $66.7 \mathrm{~g} /$ week in 1st, 2nd and 3rd weeks, respectively) was in cell $\mathrm{F}_{3} \mathrm{~S}\left(2800 \mathrm{~cm}^{2}\right.$ pen $)$, while there were weight losses in $2400 \mathrm{~cm}^{2}$ pen in Figs. 1a. The $\mathrm{R}^{2}$ values for $\mathrm{F}_{3} \mathrm{~S}=2800 \mathrm{~cm}^{2}$ was $0.9884 ; \mathrm{F}_{2} \mathrm{~S}$ had 0.9780 for varying floor space at constant flock sizes and $\mathrm{S}_{1} \mathrm{D}=2800 \mathrm{~cm}^{2}$ had 0.9762 highest $R^{2}$ value and $S_{3} D=5600 \mathrm{~cm}^{2}$ had 0.9717 for varying flock sizes at constant floor space per bird. There were stronger correlations between the weight gains by birds in all floor spaces or flock sizes and the number of days the birds were reared, Fig. 1a (range of $\mathrm{R}^{2}$ values between 0.889 and 0.988 ) and Fig $1 \mathrm{~b}$ (range of $\mathrm{R}^{2}$ values between 0.962 and 0.976 ).

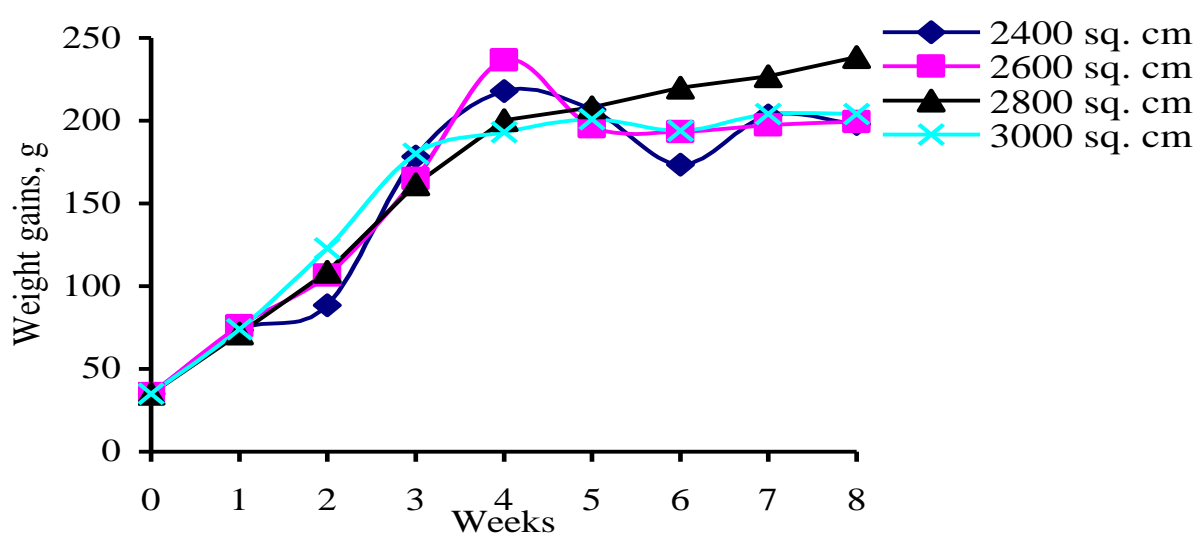

a).Figure 1: Average weekly weight gains of birds in: (a). varying floor space pens (b). varying stocking densities 


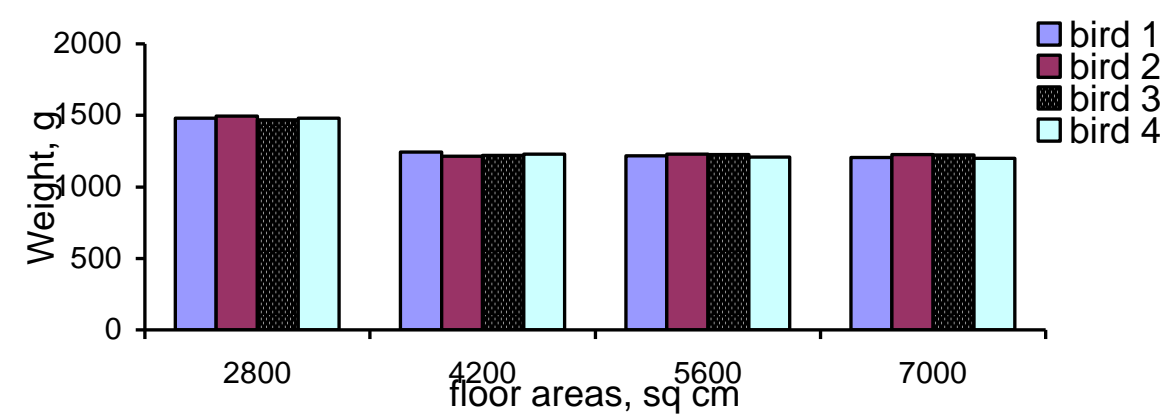

a) Figure 2: Uniformities of birds' weights in their individual pens in: (a). varying floor space pens and (b). varying stocking densities

Table 1: Mean values of weight gain and proximate analysis for floor spaces (FS) and stocking densities (SD) variations

\begin{tabular}{|c|c|c|c|c|}
\hline \multicolumn{5}{|l|}{ Floor space } \\
\hline & $\mathrm{F}_{1} \mathrm{~S}$ & $\mathrm{~F}_{2} \mathrm{~S}$ & $\mathrm{~F}_{3} \mathrm{~S}$ & $\mathrm{~F}_{4} \mathrm{~S}$ \\
\hline $\begin{array}{l}\text { Weight } \\
\text { gain, kg }\end{array}$ & $1.728 \pm 5.025^{\mathrm{c}}$ & $1.759 \pm 0.36^{\mathrm{b}}$ & $1.81 \pm 0.75^{\mathrm{a}}$ & $1.717 \pm 0.783^{\mathrm{ab}}$ \\
\hline Dressed & $1.385 \pm 5.023^{\mathrm{c}}$ & $1.407 \pm 6.646^{\mathrm{ab}}$ & $1.4804 \pm 4.027^{\mathrm{a}}$ & $1.408 \pm 6.665^{\mathrm{ab}}$ \\
\hline \multicolumn{5}{|l|}{ Weight, kg } \\
\hline Protein, $\%$ & $19.87 \pm 0.23^{\mathrm{c}}$ & $19.29 \pm 1.05^{\mathrm{b}}$ & $23.17 \pm 2.015^{\mathrm{a}}$ & $21.26 \pm 0.05^{\mathrm{ab}}$ \\
\hline Ether,\% & $1.19 \pm 0.5^{\mathrm{ab}}$ & $1.007 \pm 0.56^{\mathrm{b}}$ & $2.013 \pm 1.01^{\mathrm{a}}$ & $0.943 \pm 0.02^{\mathrm{c}}$ \\
\hline Ash, $\%$ & $0.62 \pm 0.2^{\mathrm{c}}$ & $0.753 \pm 1.45^{\mathrm{b}}$ & $0.80 \pm 0.01^{\mathrm{a}}$ & $0.713 \pm 0.05^{\mathrm{ab}}$ \\
\hline Fibre, $\%$ & $0.753 \pm 0.2^{\mathrm{b}}$ & $1.273 \pm 0.05^{\mathrm{a}}$ & $0.353 \pm 1.01^{\mathrm{c}}$ & $0.38 \pm 0.023^{\mathrm{ab}}$ \\
\hline Moisture, $\%$ & $77.57 \pm 0.2^{\mathrm{c}}$ & $77.67 \pm 0.05^{\mathrm{ab}}$ & $73.67 \pm 0.02^{\mathrm{c}}$ & $77.63 \pm 0.03^{\mathrm{a}}$ \\
\hline
\end{tabular}

Stocking Density

\begin{tabular}{|c|c|c|c|c|}
\hline & $\mathrm{S}_{1} \mathrm{D}$ & $\mathrm{S}_{2} \mathrm{D}$ & $\mathrm{S}_{3} \mathrm{D}$ & $\mathrm{S}_{4} \mathrm{D}$ \\
\hline $\begin{array}{l}\text { Weight } \\
\text { gain, } \mathrm{kg}\end{array}$ & $1.81 \pm 1.563^{\mathrm{a}}$ & $1.534 \pm 1.957^{\mathrm{b}}$ & $1.530 \pm 1.981^{\mathrm{ab}}$ & $1.523 \pm 1.986^{\mathrm{ac}}$ \\
\hline Dressed & $1.482 \pm 1.352^{\mathrm{a}}$ & $1.227 \pm 1.302^{\mathrm{ab}}$ & $1.224 \pm 1.301^{\mathrm{c}}$ & $1.218 \pm 1.315^{\mathrm{ab}}$ \\
\hline Weight, $\mathrm{kg}$ & & & & \\
\hline protein, $\%$ & $23.29 \pm 0.15^{\mathrm{a}}$ & $21.26 \pm 1.01^{\mathrm{b}}$ & $20.01 \pm 1.01^{\mathrm{ab}}$ & $19.88 \pm 0.00^{\mathrm{c}}$ \\
\hline ether, $\%$ & $2.12 \pm 0.05^{\mathrm{b}}$ & $0.597 \pm 0.06^{\mathrm{a}}$ & $0.667 \pm 0.01^{\mathrm{ab}}$ & $0.907 \pm 0.01^{\mathrm{c}}$ \\
\hline ash, $\%$ & $0.893 \pm 0.02^{\mathrm{a}}$ & $0.853 \pm 0.05^{\mathrm{b}}$ & $0.72 \pm 0.01^{\mathrm{c}}$ & $0.717 \pm 0.04^{\mathrm{ab}}$ \\
\hline fibre, $\%$ & $0.383 \pm 0.00^{\mathrm{a}}$ & $0.637 \pm 0.03^{\mathrm{b}}$ & $0.503 \pm 1.11^{\mathrm{c}}$ & $0.50 \pm 0.03^{\mathrm{ab}}$ \\
\hline moisture, $\%$ & $73.30 \pm 1.02^{\mathrm{c}}$ & $76.64 \pm 0.92^{\mathrm{ab}}$ & $78.10 \pm 0.88^{\mathrm{c}}$ & $78.00 \pm 0.13^{\mathrm{a}}$ \\
\hline
\end{tabular}

Mean values along the same row with the same superscript are not statistically different at $\mathrm{P} \leq 0.05$. 
Table 2: Mean values of Feed Conversion Ratio (FCR) and Feed Efficiency (FE) of Broilers under varying floor space, constant stocking density

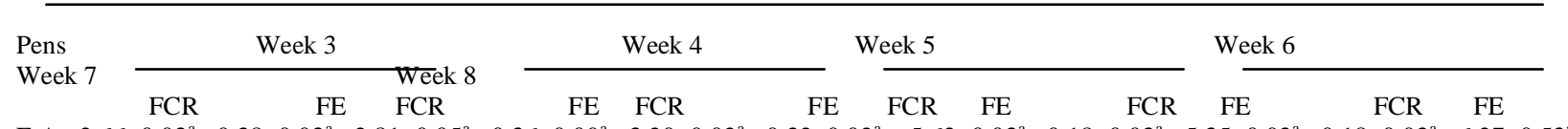

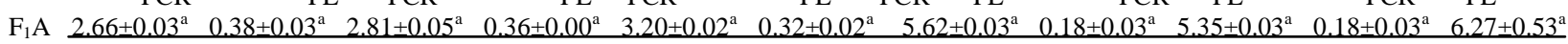
$0.15 \pm 0.03^{\mathrm{a}}$

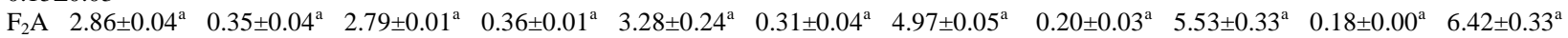
$0.16 \pm 0.00^{\mathrm{a}}$

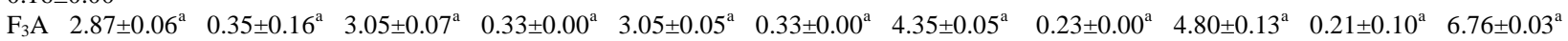
$0.18 \pm 0.03^{\mathrm{a}}$

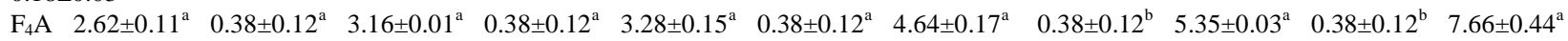
$0.38 \pm 0.12^{\mathrm{a}}$
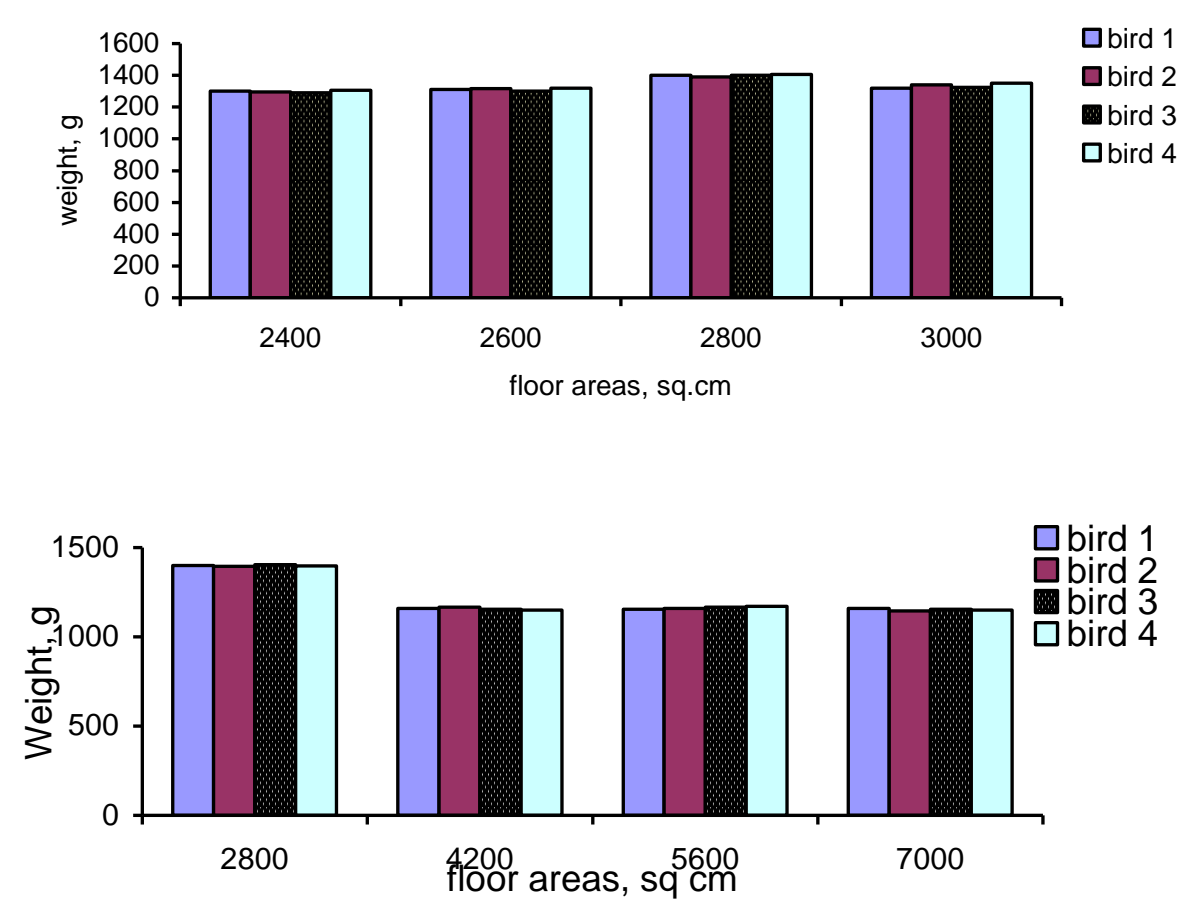

Figure 3: Birds' carcass weights in their individual pens in: (a). varying floor space pens and (b). varying stocking densities

Table 3: Mean values of Feed Conversion Ratio (FCR) and Feed Efficiency (FE) of Broilers under varying stocking density, constant floor space.

\begin{tabular}{|c|c|c|c|c|c|c|c|c|c|c|c|c|}
\hline \multirow{2}{*}{$\begin{array}{l}\text { Pens } \\
\text { Week } 7\end{array}$} & \multicolumn{3}{|c|}{ Week 3} & \multicolumn{3}{|c|}{ Week 4} & \multicolumn{3}{|c|}{ Week 5} & \multicolumn{3}{|l|}{ Week 6} \\
\hline & FCR & $\mathrm{FE}$ & FCR & $\mathrm{FE}$ & FCR & FE & FCR & FE & FCR & FE & FCR & $\mathrm{FE}$ \\
\hline \multicolumn{2}{|c|}{$\begin{array}{l}\mathrm{S}_{1} \mathrm{~A} \quad 3.18 \pm 0 \\
0.18 \pm 0.01^{\mathrm{a}}\end{array}$} & $0.32 \pm 0.01^{\mathrm{a}}$ & $3.00 \pm 0.01^{\mathrm{a}}$ & $0.37 \pm 0.01^{b}$ & $3.13 \pm 0.02^{\mathrm{a}}$ & $0.32 \pm 0.02^{\mathrm{a}}$ & 4.46 & $\pm 0.05^{\mathrm{a}}$ & $0.23 \pm 0.02^{\mathrm{b}}$ & $4.90 \pm 0.03^{\mathrm{b}}$ & $0.21 \pm 0.03^{\mathrm{a}}$ & $5.44 \pm 0.13^{\mathrm{b}}$ \\
\hline \multicolumn{2}{|c|}{$\begin{array}{l}0.18 \pm 0.01 \\
\mathrm{~S}_{2} \mathrm{~A} \quad 3.15 \pm 0.20^{\mathrm{a}}\end{array}$} & $0.32 \pm 0.00^{\mathrm{a}}$ & $2.76 \pm 0.18^{\mathrm{a}}$ & $0.36 \pm 0.06^{\mathrm{b}}$ & $3.44 \pm 0.01^{\mathrm{a}}$ & $0.30 \pm 0.01^{\mathrm{a}}$ & a 8.15 & $\pm 0.08^{b}$ & $0.13 \pm 0.01^{\mathrm{a}}$ & $7.76 \pm 0.43^{\mathrm{a}}$ & $0.13 \pm 0.01^{\mathrm{a}}$ & $7.49 \pm 0.44^{\mathrm{a}}$ \\
\hline \multicolumn{2}{|c|}{$\begin{array}{l}\mathrm{S}_{3} \mathrm{~A} \quad 2.95 \pm 0.03^{\mathrm{a}} \\
0.15 \pm 0.03^{\mathrm{a}}\end{array}$} & $0.34 \pm 0.03^{\mathrm{a}}$ & $3.70 \pm 0.05^{\mathrm{a}}$ & $0.27 \pm 0.00^{\mathrm{a}}$ & $3.86 \pm 0.02^{\mathrm{a}}$ & $0.27 \pm 0.02^{\mathrm{a}}$ & a 6.03 & $\pm 0.03^{\mathrm{a}}$ & $0.17 \pm 0.03^{\mathrm{a}}$ & $6.80 \pm 0.03^{\mathrm{a}}$ & $0.15 \pm 0.03^{\mathrm{a}}$ & $7.02 \pm 0.03^{\mathrm{a}}$ \\
\hline \multicolumn{2}{|c|}{$\begin{array}{l}\mathrm{S}_{4} \mathrm{~A} \quad 2.91 \pm 0.04^{\mathrm{a}} \\
0.13 \pm 0.00^{\mathrm{a}}\end{array}$} & $0.31 \pm 0.04^{\mathrm{a}}$ & $3.62 \pm 0.01^{\mathrm{a}}$ & $0.25 \pm 0.01^{\mathrm{a}}$ & $3.62 \pm 0.24^{\mathrm{a}}$ & $0.28 \pm 0.04^{\mathrm{a}}$ & a 5.94 & $\pm 0.05^{\mathrm{a}}$ & $0.17 \pm 0.03^{\mathrm{a}}$ & $6.37 \pm 0.33^{\mathrm{a}}$ & $0.16 \pm 0.00^{\mathrm{a}}$ & $7.73 \pm 0.33^{\mathrm{a}}$ \\
\hline
\end{tabular}


Evaluation of Performances of Broilers Raised Under Different Floor Space Eometries

The cumulative weight gains on the average per bird from $0-8$ weeks in pen $2800 \mathrm{~cm}^{2}$ were $180.60 \pm 0.755$ $\mathrm{g}$ for the varying floor space and $180.83 \pm 1.563 \mathrm{~g}$ for the varying stocking densities. Others were $175.90 \pm$ $0.36 \mathrm{~g}$ and $174.00 \pm 2.043 \mathrm{~g}$ for $2600 \mathrm{~cm}^{2}$ and 2000 $\mathrm{cm}^{2}$, respectively for the varying floor spaces. Figures 2 and 3 show the weights' uniformity and birds' carcass yield, respectively, for four birds investigated while alive and while dead in each pen. The Figures show that for the $2600 \mathrm{~cm}^{2}$ and $2800 \mathrm{~cm}^{2}$ pens, birds' weights were uniform, Feddes et al. (2006) also reported such uniformity in different FS of $0.45,0.60$, 0.75 and $0.90 \mathrm{ft}^{2} /$ bird. No such uniformity was found in other two pens, however, $2800 \mathrm{~cm}^{2}$ pen has the highest liveweight. The average final weight for $2400 \mathrm{~cm}^{2}$, $2600 \mathrm{~cm}^{2}, 2800 \mathrm{~cm}^{2}$ and $3000 \mathrm{~cm}^{2}$ were $1382.0 \pm$ $7.023 \mathrm{~g}, 1407.0 \pm 6.646 \mathrm{~g}, 1480.0 \pm 4.028 \mathrm{~g}$ and 1408.0 $\pm 6.665 \mathrm{~g}$ respectively, and for the average carcass yield: $1162.0 \pm 3.46 \mathrm{~g}, 1200.0 \pm 4.232 \mathrm{~g}, 1255.0 \pm 6.25$ $\mathrm{g}$, and $1130.0 \pm 5.26 \mathrm{~g}$, respectively. However, in Figures 2 and 3, some factors may be posited as those factors that made the weight gains to level off after four weeks of the rearing of the birds. These factors were their competition for feed, competition for water and space and their eventual dominance over each other which led to different behavioural, sociological and psychological characters among the birds. These characters resulted in stronger birds dominating over the weaker ones, the weightier birds suppressing the less weightier and the multiplier effects on the weaker and less weightier birds which made them to have further reduced weights and sizes. These were mostly observed in cells in pens $S_{2} D, S_{3} D$ and $S_{4} D$, Table 1.

Figures $4 a$ and $b$ show the mean values of the daily temperature profiles of the litter at varying floor spaces and varying flock sizes, respectively. Both show that the trend of temperature fluctuates with days, since birds are homothermic animals. This fluctuating trend affected their feed consumption and their feed conversion ratio (FCR), Table 2, this in turn affected their carcass weights Figs. $1 \mathrm{a}$ and $\mathrm{b}$ and $2 \mathrm{a}$ and $\mathrm{b}$. This result agrees with May et al. (1997) who reported similar result for birds raised with same feeding and drinking.

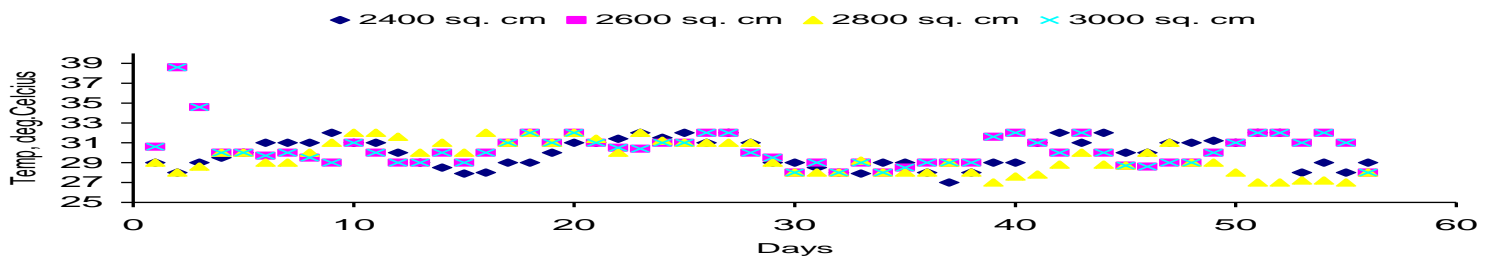

b).

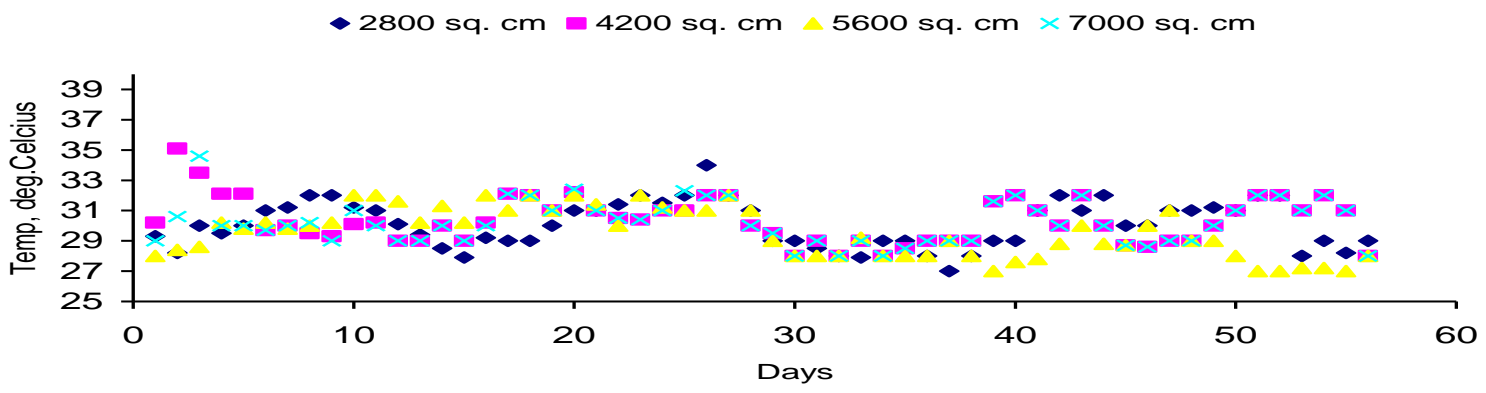

Figure 4: Daily mean Temperature profiles of the litter in pens in: (a). varying floor 
Wasiu Agunbiade Lamidi

a).
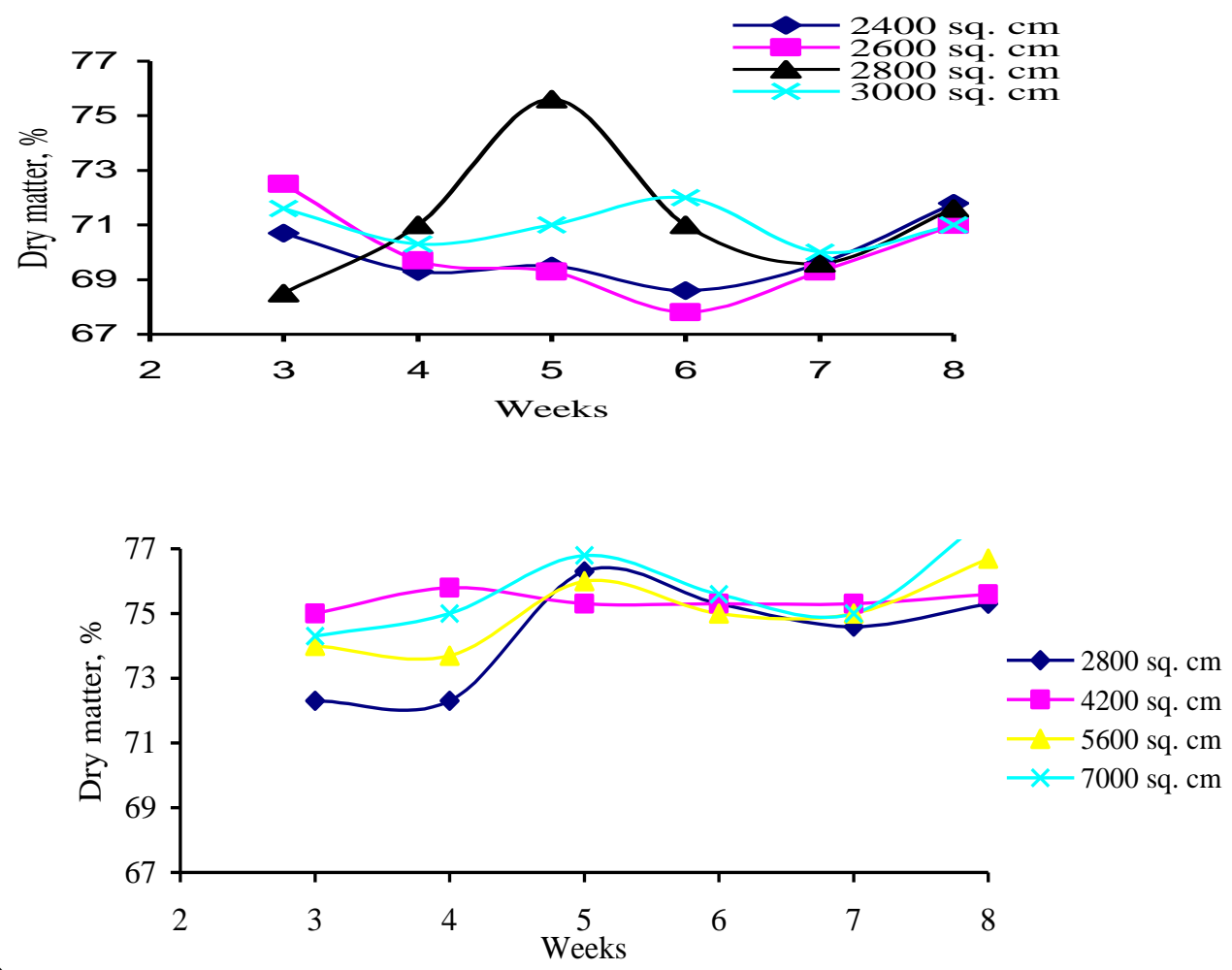

b).

Figure 5: Average weekly \% dry matter content of litter in: (a). varying floor space

pens and (b). varying stocking densities

The rate of production of litter droppings in the birds was related to their rate of feeding, their health at the period, their breed, age and sex, the cumulative environmental inclinations on the bird and the management as provided by the owner. The litter's dry matter content was high in all the pens in Fig. 5 b. Since the more the dry matter content of the litter, the less food could have been digested or effectively assimilated. Therefore, birds in Fig. 5b of stocking density variations had less feed efficiency FE than those in FS pens, Table 2. The $\mathrm{R}^{2}$ values in Figures 5a, b were low. The $\mathrm{R}^{2}=0.91$ for $3000 \mathrm{~cm}^{2}$ in Fig. $5 \mathrm{~b}$, for 2400, 2600 and $2800 \mathrm{~cm}^{2}$, their $\mathrm{R}^{2}$ values were 0.93 , 0.94 and 0.70 respectively, signifying stronger correlations between SD and dry matter percentage of the litter.

Figures $6 a$ and $b$, and $7 a$ and $b$ show the graphical representation of the daily weight of the litter and its $\mathrm{pH}$ respectively. Fig. 6a and $\mathrm{S}_{2} \mathrm{D}(0.98)$ followed by $S_{1} D(0.97)$ in Fig. 6b. This shows stronger correlation between the SD and the birds' weekly average weights of the litter. In Figure $7 b$, the $R^{2}$ value of the $S_{3} D\left(7000 \mathrm{~cm}^{2} / 10\right.$ birds $)$ was 0.98 , this was higher than others. Also, its $\mathrm{pH}$ values were higher because of increased SD, Figures. 7a, b. The $\mathrm{R}^{2}$ values proved to be higher for $\mathrm{F}_{3} \mathrm{~S}$ (0.99), followed by $\mathrm{F}_{1} \mathrm{~S}$ (0.97). This shows stronger correlations between the FS, SD and the birds' litter $\mathrm{pH}$ values. 
a).

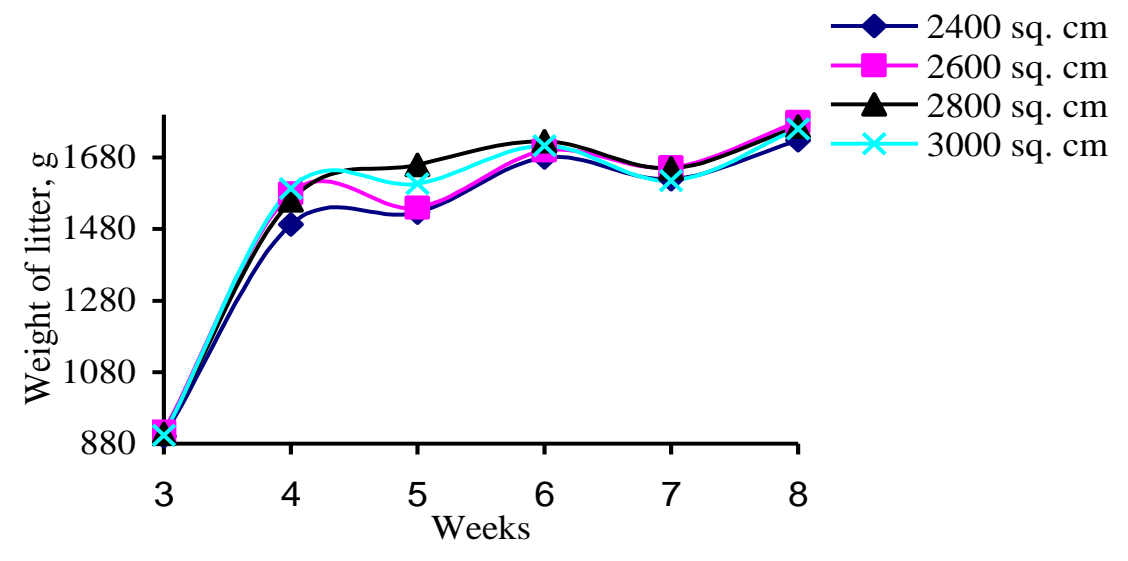

b).

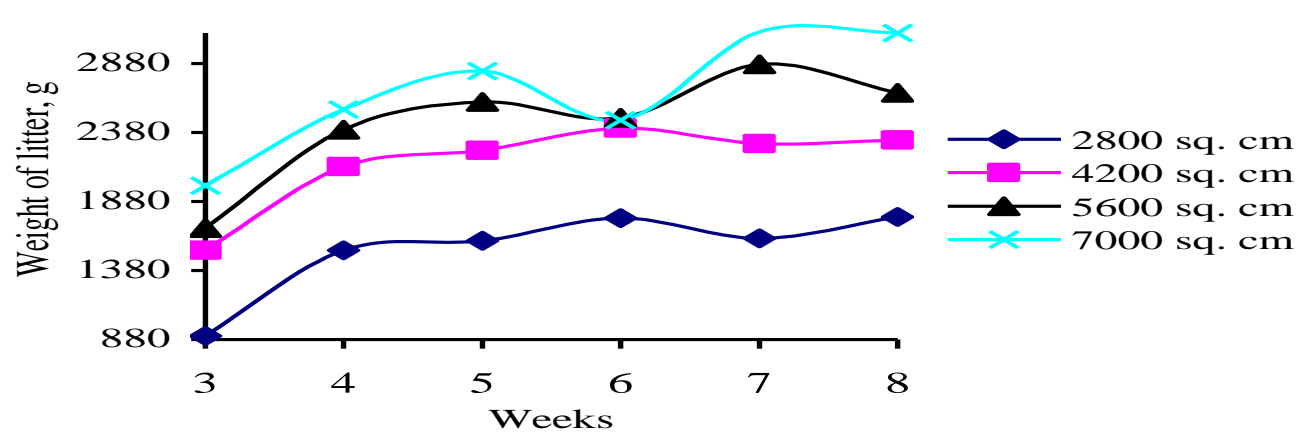

Figure 6: Average weekly weight of litter in: (a). varying floor space pens and (b). $\quad$ varying stocking densities

On proximate analysis, significant effects $(\mathrm{P} \leq 0.05)$ of the floor space area were observed on ether extract and protein in FS and also, significant effects $(\mathrm{P} \leq 0.05)$ of the flock size were observed respectively, on ether extract and crude fibre in SD. On the mean values of the proximate analysis in Table 1, statistical differences were observed for all the proximate values in $\mathrm{F}_{3} \mathrm{~S}$ and $\mathrm{S}_{1} \mathrm{D}$ and in $\mathrm{F}_{1} \mathrm{~S}$.

The more alkaline nature of the litter, Fig. 7, implies that the litter contains more organic matter. This led to slow degradation of uric acid in $\mathrm{S}_{4} \mathrm{D}$ resulting in volatilization of water vapour and carbondioxide. This could be because of more trampling done with legs in the pen of 10 birds than in
4 birds pen in $S_{1} D$ or 6 birds in $S_{2} D$; (no matter the area of the pen, all the spaces therein were opened to the birds). The litter in $\mathrm{S}_{1} \mathrm{D}$ had the lowest alkalinity, 8.3 and 9.3 , Fig. $7 b$; because of fewer trampling of the litter which could have mean that more microorganisms were at work in $S_{1} D$ than $S_{2} D$, then slower in $S_{3} D$ in hastening the degradation and volatilization processes. All these could have happened because of: (1) as the litter was trampled on where flock sizes were high- SD pens, the less the microbial activities therein, the rate of ammonia emission could be reduced. (2) also, there would be more weight of litter and dry matter contents because of more birds, because of these, volatilization of water vapour and carbondioxide 
and the degradation processes of uric acid could happened per unit area space. (3) again, these rates increased with the number of days the litter might have spent in the pen before removal and (4) litter's contents were also function of the type of feed and the environmental conditions where the birds are reared (Turkyilmaz, 2006). All these contributed to the variations in FCR and FE in the broilers. The FCR values were highest in birds with floor space $S_{2} D=$ $4200 \mathrm{~cm}^{2}$ and $\mathrm{S}_{1} \mathrm{D}=2800 \mathrm{~cm}^{2}$ having $8.15 \pm 0.03$ and $7.73 \pm 0.33$ respectively, Table 1 . Similarly, in Table 2 ,
FE values were highest in birds kept at lower stocking density with floor space $\mathrm{S}_{1} \mathrm{D}=2800 \mathrm{~cm}^{2}, \mathrm{~F}_{3} \mathrm{~S}=2800$ $\mathrm{cm}^{2}$ and $\mathrm{F}_{1} \mathrm{~S}=2400 \mathrm{~cm}^{2}$, respectively with values of $0.38 \pm 0.12,0.37 \pm 0.01$ and $0.38 \pm 0.03$. The same report by Feddes et al. (1999) and Stewart (1996) that lower flock sizes gave highest FE. This shows that birds in $\mathrm{F}_{1} \mathrm{~S}, \mathrm{~F}_{3} \mathrm{~S}$ and $\mathrm{S}_{1} \mathrm{D}$ had high $\mathrm{FCR}$ resulting in low feed utilization efficiency, FE and have more weight gains than other birds in other pens, Figures $2 b$, $3 b$.

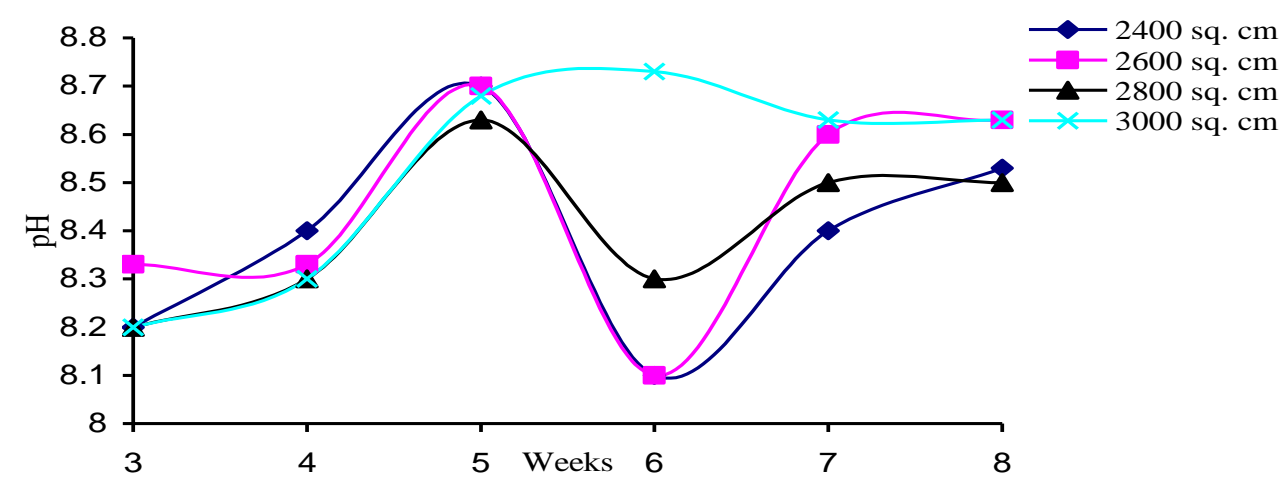

b).

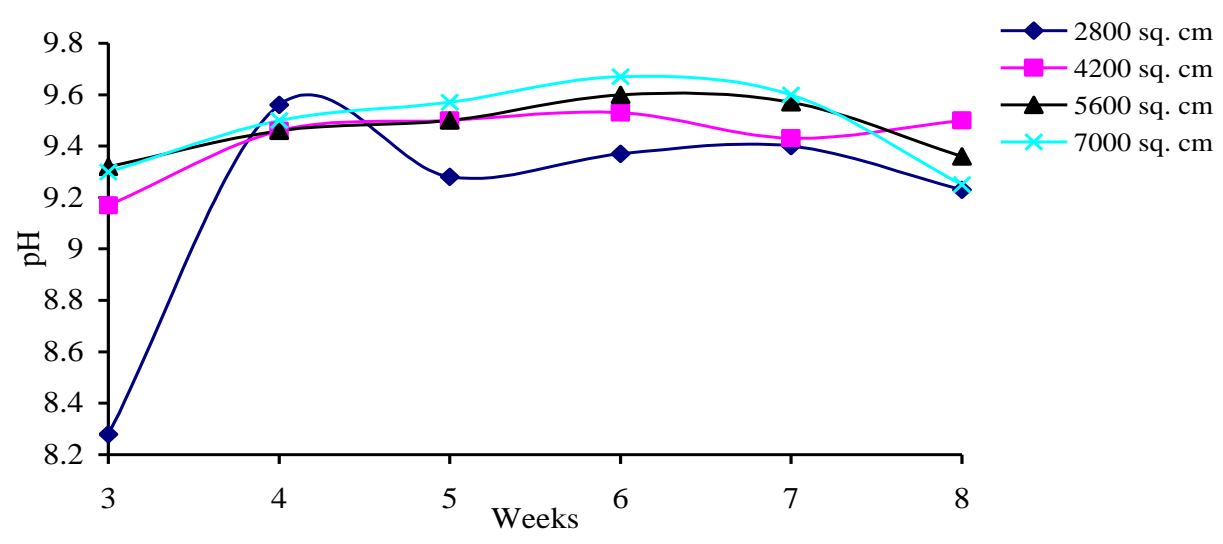

Figure 7: Average weekly pH values of litter in: (a). varying floor space pens and

(b). varying stocking densities 
Birds in $2800 \mathrm{~cm}^{2}$ pens had highest live and dressed weights (carcass weights) of birds recorded, Figures $2 \mathrm{~b}, 3 \mathrm{~b}$. This shows that the floor space $700 \mathrm{~cm}^{2}$ per bird was capable of giving maximum yield of carcass at both liveweight and dressed weight. The results of the proximate analysis show that floor spaces and flock sizes have significant effects on the meat quality of the birds as shown by p-values and statistical differences for the ether extract and protein.

\section{CONCLUSION}

The following conclusions were made:

Floor space $2800 \mathrm{~cm}^{2} / 4$ birds, that is, $700 \mathrm{~cm}^{2}$ per bird revealed more correlation between carcass weight and flock size/stocking density, SD and floor space area FS. The uniformities in birds' weights were moderate and also higher carcass yield (1450.0 \pm 5.66) was recorded in $2800 \mathrm{~cm}^{2} / 4$ birds. Also, FCR values were highest in birds with floor spaces $F_{1} S$ and $S_{1} D=2800$ $\mathrm{cm}^{2}$. In practice, the combination of $700 \mathrm{~cm}^{2}$ floor space per bird or $70 \mathrm{~m}^{2}\left(700,000 \mathrm{~cm}^{2}\right)$ floor space for 1000 flock size will give higher meat productivity in broilers raised in the tropics.

\section{ACKNOWLEDGEMENTS}

I appreciate the permission of the Teaching and Research Farm of the Obafemi Awolowo University, Ile-Ife in Nigeria to use their facilities for the research.

\section{REFERENCES}

Agric Business Week (2010). Broilers: Rearing Optimum Broiler Breeders. Agric Business week, crops, aquaculture, livestock poultry and agrithing. 2010 year end- Food and Agro Business.

Bonazz, I, G., Valli, L. and Piccinini, S. (1987). Controlling Ammonia Emissions from Poultry Manure Composting Plants. In: Volatile Emissions from Livestock Farming and Sewage Operations Eds : Nielsen V.C, Voorburg J.H and 1'Hermite P) Proceedings of a Workshop at Uppsale, Sweden 10-12 June, Elsevier, London/New York 96, 183-195.

British Codes (2000). British code in floor space and stocking density for broiler chickens. Codes of practice for the care and handling of farm animals.

Bruce, J. M. (1987). The Environmental Requirements of Livestock. Agricultural Engineer Winter 1987: 137-140.
Crawford, R. D. (1990). Poultry Breeding and Genetics. Elsevier Publication Co., New York, USA.

Feddes, J. J. R., Emmanuel, R. H. and Zuidoff, M. J. (2006). Health Implications for Higher Density Broiler Production. Poultry article for Poultry site, September $2006 . \quad$ Accessed 27/6/2010

Feddes, J. J. R., Emmanuel, R. H., Macgovern, R. H. and Zuidoff, M. J. (1999). Broiler

Performance, Weight Variance, Feed and Water Intake and carcass Quality at different Stocking Density. Poultry Research Centre News - 8 (2): 13-23. Broiler Breeders on line - http://www.agric.gov.ab.ca/aprc/

Goksoy, E. O., McIntyre, L. J., Parkman, I., Philips, A., Richardson, R. I. and Anil, M. H. (1999). Broiler Stunning and Meat Quality. Poultry Science Journal, 78: 1796-1800

Groot Koerkamp, P. W. G. (1995). Reduction of Ammonia Emission in Aviary Housing for Laying Hens. Eds: Blockhius H. J and Metz J. H. M) IMAG- DLO, Wageningen, The Netherlands Report 95-31: 117-129.

Hall, A. L. (2001). Effect of Stocking Density on the Welfare and Behaviour of Broiler Chicken Reared Commercially. Animal Welfare 10 (1): 23-40

Jakobsen, S. T. (1987). Ammonia Volatisation during Composting of Straw and Slurry. In: Proceedings from 4th International Symposium of CIEC 11-14 May, Braunschweig, Germany, 283-291.

May, J. D., Lott, B. O. and Simmons, J. D. (1997). Water Consumption by Broilers in High Cyclic Temperatures: Bell versus Nipple Waterers. Journal of Poultry Science 76: 944 947.

Stewart, J. R. (1996). Health Implication for Higher Density Broiler Production. Canadian Poultry Consultants Ltd/S.J. Ritchie Research Farms Ltd. 21 ${ }^{\text {st }}$ Annual PSIW Alberta Agriculture, Food and Development, pp 1-8.

Turkyilmaz, M. K. (2006). The Effect of Stocking Density on Stress Reaction in Broiler Chicken during Summer. Turk Journal of Vet. Animal Science 32 (1): 31-36.

Vegetarian Society Information Sheet (2003). Broiler chickens Broiler chickens information sheets 12 and 22 